\title{
Microbial Simulation Experiment on Enhancing Coalbed Methane Production
}

Chen Hao, ${ }^{1,2,3}$ Qin Yong, ${ }^{1,2}$ Zhou Shangwen, ${ }^{3}$ Wang Hongyan, ${ }^{3}$ Chen Zhenhong, ${ }^{3}$ Li Guizhong ${ }^{3}$ Deng $\mathrm{Ze}^{3}$ and Cheng $\mathrm{Lei}^{4}$

(1.Key Laboratory of CBM Resource and Reservoir Formation Process, Ministry of Education,China University of Miningand Technology, Xuzhou 221008, China

2.School of Resources and Geosciences, China University of Mining and Technology, Xuzhou, China

3. Research Institute of Petroleum Exploration and Development-Langfang Branch, Langfang, Hebei Province, 065007;

4. Biogas Research Institute of the Ministry of Agriculture, Chengdu, Sichuan Province. 610041)

Abstract: Coalbed Methane (CBM) production enhancement for single wells is a big problem to CBM industrialization. Low production is due to insufficient gas generation by thermogenic. Luckily, Biogenic gas was found in many areas and its supply is assumed to improve coalbed methane production. Therefore, microbial simulation experiment will demonstrate the effectiveness of the assumption. From microbial simulation experiment on different coal ranks, it is found that microbes can use coals to produce biogas under laboratory conditions. With different temperatures for different experiments, it turns out that the gas production at $35^{\circ} \mathrm{C}$ is greater than that at $15^{\circ} \mathrm{C}$,indicating that $35^{\circ} \mathrm{C}$ is more suitable for microbes to produce gas. According to quantitative experiments, adding exogenous nutrients or exogenous bacteria can improve CBM production. Moreover, the production enhancement ratio can reach up to $115 \%$ under the condition of adding exogenous bacterial species, while the ratio for adding nutrients can be up to $144 \%$.

Key words: Coalbed Methane (CBM) ; Methanogens; Biogenic Gas; CBM Production Enhancement

\section{1.introduction}

Coal-bed methane (CBM), or coal-bed natural gas, is an unconventional gas that has become an emerging and important energy resource worldwide(Strapoc D,2011;Park SY,2016). As is known to all, China has huge potential resources in coalbed methane (CBM)(Zhang,2018). According to the maturity of coals, $\mathrm{CBM}$ can be divided into low rank $\mathrm{CBM}\left(\mathrm{R}_{\mathrm{O}}<0.7\right)$, medium rank $\mathrm{CBM}\left(0.7<\mathrm{R}_{0}<1.3\right)$ and high rank $\mathrm{CBM}(\mathrm{RO}>1.3)$. So far, the high and medium ranks CBM have made a major breakthrough and has been under commercial production at Qinshui Basin and Ordos Basin. But low rank CBM, accounting for $40 \%$ of the national resources, is relatively slow in exploration. The main reason for it is the limited amount of gas production due to low thermal evolution. Moreover, the sweet spot for biogas is hard to discover and CBM production is generally low in most exploration areas. In addition, as coal basins have mostly experienced one or more of the tectonic uplift movements in China, the thermal evolution is slow or stagnant after 
the rise of coal seams. At the same time, the formation pressure decreases due to the uplift, a large amount of gas has escaped and the coal seam is small in adsorption quantity, leading to low output. Some areas, however, the atmospheric fresh water brings in a large number of biological bacteria(Zhang J,2015,2017; Wei M,2014). Under their action, small molecules are broken down into methane in coal seams, which can be adsorbed by coal beds to form favorable CBM reservoirs (Ahmed,2001;M,Martini A,2008;Alexei V,2011;). In view of this, the coalbed methane production could be improved by the introduction of biological bacteria with artificial methods(Rathi R,2015;Kirk MF,2015;Robbins SJ,2015).Therefore,microbial simulation experiment on enhancing CBM production is of great practical significance on CBM exploration and development.

A number of studies related to biogas simulation experiment haven been conducted abroad(Jones EJP,2008,2010; Haider,2013,2014,2018).Scott(1999)proposed the concept of "microbially enhanced coalbed methane" , that is, with bacteria and nutrients injected into coals, methane is generated by the biodegradation of coals, asphaltenes and waxes so as to increase methane production in coal seams. Other studies show that the organic matter rich in small molecules, can be utilized for microbes to produce gas. Recently, some institutions in the United States have carried out a lot of work and trials to improve production by microbes(Priyadarshani,2012; Colosimo F, 2016; Park SY, 2016). In their approaches, firstly, find out the nutrient formulations suitable for the growth of the microbial community and then inject them into underground, thus realizing the conversion of coals into methane(Zehnder,1988; Dariusz,2011,Davis KJ,2018). All these show in terms of the industrial production scale, it is feasible for coals to be converted into methane by microbes. Meanwhile, domestic scholars (Li,1996;Wang,2010) have adopted the anaerobic culture method and have developed active anaerobic bacteria in lignite samples in Zhaotong city, Yunnan province ,China. A follow-up 60-day experiment on methane generation has been carried out, and biogas generation laws, composition and formation mechanism have also been analyzed. The results reveal that the lignite with the reduction environment is beneficial to the prosperity of methanogens in Zhaotong Basin. Biogas generation has undergone three stages: slow growth, significant increase and slow down, which show that methanogens will reach a higher level in quantity and activity in the second stage after slow reproduction in the first stage. Moreover, there are at least two or more peak stages for biogas generation in lignite coals (Wang BY, 2010; Yang XQ,2018).

\section{Mechanism Analysis of Gas Generation by Microbes}

Biogenic coalbed methane is considered to comply with anaerobic fermentation theory (Li,1996; Wawrik B,2012). Animals, plants, and other living things are degraded into macromolecular organic matter by the consumption of aerobic microbes after burial, and then the formation is gradually transited from aerobic to anaerobic environment due to constant consumption of oxygen. There are three stages in the anaerobic ecosystem. The first stage is for 
organic monomers to decompose into reduced organic compounds, in which carbohydrates, protein, lipid and other macromolecular organic polymer are fermented into sugar, amino acids, fatty acids, glycerol and other organic monomers by hydrolysis or fermentative bacteria, and then the organic monomers are hydrolyzed into educed organic compounds, such as propanoic acids, butyric acids, lactic acids and alcohols. The second stage is for reduced organic compounds to decompose into $\mathrm{CO} 2$ and acetic acid, in which the intermediate products are further decomposed by obligate hydrogenogens and acetogens into acetic acid, $\mathrm{CO} 2$, formic acid and methanol, $\mathrm{C} 1$ compounds such as methylamine and hydrogen. The decomposition is divided into two situations: 1)In the geological system with the presence of nitrate and sulfate, the electrons firstly flow to nitrate and sulfate, and then through metabolism of bacteria reduction of the nitrate and sulfate, oxidize the reduced organic matter into $\mathrm{CO} 2$ and acetic acid; 2)In the ecological environment with the presence of nitrate and sulfate, the electrons directly flow to $\mathrm{CO}$. The third stage is the methane production phase, in which acetic acid is composed of $\mathrm{CO}$ (or $\mathrm{HCO}-$ ) and hydrogen by homoacetogen, and then methane is generated by fermentation of the acetic acid. Or methane is generated from $\mathrm{CO} 2$ by methanogens utilization of coenzyme $\mathrm{M}$ reduction system during the anaerobic respiration metabolism process or from other $\mathrm{C} 1$ compounds by other fermentation paths (Walter B,2002;Dariusz,2011). Therefore, the formation of biogas can be attributed to the reduction of $\mathrm{H} 2+\mathrm{CO} 2$ and the fermentation of acetic acid and methyl.

\section{Method and Process of Biogas Simulation Experiment}

\subsection{Sample Source and Basic Characteristics}

The samples are collected from Qinshui Basin and Ordos Basin with representative coals of different ranks. All the samples are fresh coals which have been taken out rapidly from coal mines, sealed by plastic wrap and then transported to the laboratory in the shortest time, thus guaranteeing the samples to be sealed in anaerobic state to the greatest extent.

The original plant composition and contribution of different plant parts result in the different coal composition expressed by coal macerals. Macerals are microscopically recognizable organic entities in coal. They are distinguished microscopically by color, shape, morphology, and degree of preservation of the cell structure, reflectance level, and intensity of fluorescence. Macerals were introduced by analogy to minerals in rocks (Stopes 1935). There is, however, a major difference between the concept of minerals and that of macerals. The vitrinite group represents woody plant material (e.g., stems, trunks, roots, and branches)that is derived from the lignin and cellulose of plant tissues (Taylor et al. 1998). Subdivision into macerals within this group depends on the degree of preservation of cell structure. The liptinite group includes components that are chemically more resistant to physical and chemical degradation than are macerals of the vitrinite group, and it includes, for example, pollen, spores, cuticles, waxes, and resins. Liptinitemacerals are enriched in hydrogen, owing to a greater amount of aliphatic components compared with the other two maceral groups. The inertinite maceral group originates from the same material as do the vitrinite group and the liptinite group but have a higher degree of aromatization and condensation. Inertinite macerals have a greater carbon content than vitrinite and liptinite group macerals at the same rank because they were carbonized, oxidized, or subjected to chemical or bacterial attacks prior to coalification, usually in the peat stage (Taylor et al. 1998, Scott \& 
Glasspool 2007). From the vitrinite reflectance and maceral tests of coal samples, Ro ranges from $0.5 \%$ to $1.32 \%$. Coal samples include different types like long flame coal, fat coal, coking coal and lean coal. Vitrinite content ranges between $6.3 \%$ and $82.6 \%$ (see table 1).

Table 1 Test results of vitrinite reflectance and maceral

\begin{tabular}{ccccccc}
\hline \multirow{2}{*}{ Sample Sites } & Coal Types & Ro & Vitrinite $(\%)$ & $\begin{array}{c}\text { Inerrinite } \\
\%)\end{array}$ & $\begin{array}{c}\text { Exinite } \\
(\%)\end{array}$ & $\begin{array}{c}\text { Mineral } \\
(\%)\end{array}$ \\
\hline ZC Coal Mine & coking coal & 1.30 & 82.6 & 16.3 & - & 1.1 \\
XL Coal Mine & coking coal & 1.31 & 65.1 & 31.1 & - & 3.8 \\
HF Coal Mine & lean coal & 1.91 & 77 & 19 & - & 4 \\
SL Coal Mine & coking coal & 1.32 & 80.2 & 16.3 & - & 3.5 \\
NLM Coal Mine & long flame coal & 0.56 & 75.8 & 18.6 & 5.3 & 0.3 \\
ZJM Coal Mine & long flame coal & 0.56 & 70.7 & 20 & 9 & 0.3 \\
SMT Coal Mine & long flame coal & 0.55 & 7.4 & 78.9 & 12.5 & 1.2 \\
ALBS Coal Mine & Fat coal & 1.11 & 71 & 7.6 & 18.9 & 2.5 \\
YJG Coal Mine & long flame coal & 0.50 & 6.3 & 85.5 & 6.9 & 1.3 \\
\hline
\end{tabular}

\subsection{Microbial Detection of Coal Samples}

\subsubsection{Microbial DNA Extraction and Sequencing of Coal Samples}

Microbial detection mainly extracts DNA from coal samples by molecular ecological means based on the test kit principle(Bi ZT,2017;Raudsepp MJ,2017). First, break the cell wall of bacteria by highly active protease(proteinase $\mathrm{K}$ )-a kind of hay protein enzymes, separate the DNA from denatured protein and other ingredients by adding Sodium dodecyl sulfate(SDS), and purify DNA using silicon matrix based on the unique adsorption principle of DNA. Then, duplicate double-stranded DNA by adding base pairs based on 16S rRNA uniqueness of PCR technology to obtain the required specific DNA banding, and finally detect the extraction quality of DNA banding under the gel electrophoresis(ChengL,2013).

\subsubsection{Metagenomics 454 Sequencing Analysis}

In this analysis, PCR products have been successfully obtained by diluting purified DNA 10 times as PCR amplification template. Due to low biomass in the coals, only samples from Shuangliu coal mine rather than Hufeng or Chengzhen coal mines have passed 454 sequencing quality tests. 1866 archaea and 8500 bacteria have been respectively obtained from the original sequence of 454 pyro-sequencing by removing low-quality sequences, primer and tag sequences from RDP database. Chao1( abundance index of bacteria and archaea species )are respectively $72 \%$ and $33 \%$ higher than corresponding OTU. Using over $97 \%$ of sequence similarity as OTU classification index, bacteria and archaea could be divided into 148 and 158 OTU respectively, 
and the sequencing results are shown in Table 2. Archaea from Shuangliu coal mines belongs to euryarchaeota phyla, and its detection results are shown in Table 3, which are mainly composed of acetic acid nutritional methanogens. Bacteria (Table 4) groups are mainly Firmicutes(54.4\%), Proteobacteria (30.9\%), uncultured microbes(10.8\%) and Thermotogae(1.26\%). Firmicutes mainly include Acidaminobacter genera, accounting for 88.3\%. Proteobacteria includes Smithella genera $(44.9 \%)$ belonging to Syntrophaceae family and Desulfovibrio genera(31\%).

\begin{tabular}{ccccccc} 
Table 2 & \multicolumn{6}{c}{ Comparison of microbial diversity estimators and coverage for Shuangliu coal samples } \\
\hline Classification & $\begin{array}{c}\text { Sample } \\
\text { Name }\end{array}$ & $\begin{array}{c}\text { Sequence } \\
\text { NO. }\end{array}$ & $\begin{array}{c}\text { OUT } \\
\text { NO. }\end{array}$ & $\begin{array}{c}\text { Avg.Fetc } \\
\text { h Length }\end{array}$ & $\begin{array}{c}\text { Coverage } \\
\text { Rate, } \%\end{array}$ & Chao1 \\
\hline Archaea & $\begin{array}{c}\text { SL Coal } \\
\text { Mine }\end{array}$ & 1866 & 158 & 491 & 0.971 & 236.79 \\
Bacteria & $\begin{array}{c}\text { SL Coal } \\
\text { Mine }\end{array}$ & 8500 & 448 & 523 & 0.912 & 769.08 \\
\hline
\end{tabular}

\begin{tabular}{llc}
\multicolumn{2}{c}{ Table 3} & Archaea Community Detection Result from 454 Pyrosequencing Analysis \\
\hline Bacterial Name & Bacterial Genus & Proportion in total sequence, \% \\
\hline Methanoculleuss & acetic acid nutritional methanogens & 85.4 \\
Methanosaeta & acetic acid nutritional methanogens & 10.2 \\
Methanolinea & Hydrogen nutritional methanogens & 0.1 \\
Haloferax & Extremely halophilic microbial group & 0.1 \\
& uncultured archaea group & 4.1 \\
\hline
\end{tabular}

\begin{tabular}{ccc}
\multicolumn{2}{c}{ Table 4 Bacterial Community Detection Result from 454 Pyrosequencing Analysis } \\
\hline Bacterial Name & Bacterial Genus & Proportion in total sequence, $\%$ \\
\hline Chlorobi & Chlorobi & 0.012 \\
Verrucomicrobia & Verrucobacteria & 0.024 \\
Acidobacteria & Soil Acidobacteria & 0.095 \\
Chloroflexi & Chloroflexi & 0.166 \\
Tenericutes & Tenericutes & 0.190 \\
Synergistetes & Obligate Gram- anaerobic bacillus & 0.012 \\
Actinobacteria & Actinobacteria & 0.213 \\
Thermotogae & Thermotogae & 1.256 \\
Bacteroidetes & Bacteroidetes & 0.249 \\
Caldiserica & & - \\
Deinococcus-Thermus & Deinococcales & 1.505 \\
Proteobacteria & Proteobacteria & 0.142 \\
Firmicutes & Firmicutes & 30.869 \\
\hline
\end{tabular}

3.3 Inorganic Medium Composition and Preparation 
The composition and preparation of inorganic salt anaerobic enrichment cultures are as follows: weigh $1 \mathrm{~L}$ distilled water, $0.5 \mathrm{~g} \mathrm{NaCl}, 0.5 \mathrm{~g} \mathrm{MgCl} 2.6 \mathrm{H} 2 \mathrm{O}, 0.1 \mathrm{~g} \mathrm{CaCl} 2.2 \mathrm{H} 2 \mathrm{O}, 0.3 \mathrm{~g} \mathrm{NH} 4 \mathrm{Cl}$, $0.5 \mathrm{~g} \mathrm{KCl}$ and $0.2 \mathrm{~g} \mathrm{KH} 2 \mathrm{PO} 4,5 \mathrm{ml}$ Soil extract, and $2 \mathrm{ml}$ trace elements of 284\# in turn[10], cool slightly after boiling, add Cysteine- $\mathrm{HCl}$ and $\mathrm{KOH}$ (5 mol) and adjust $\mathrm{PH}$ to 6.0-6.5, then add Resazurine and observe colors changing from blue to red to colorless, continue heating after boiling, with anaerobic N2 inlet in, adjust temperature to keep the cultures under boiling for about 30min, continue further to inlet $\mathrm{N} 2 / \mathrm{CO} 2$ mixture, and then transfer it into the bucket with ice, and finally keep some portions under the protection of $\mathrm{N} 2$, and keep sterilization for 30 minutes at $121^{\circ} \mathrm{C}$ (WiddelF,2006,Barnhart EP,2013,2016).

\subsection{Experiment Design}

First grind coal samples to 60 mesh, remove residual gas in the coal seams and pack samples into each group of $10 \mathrm{~g}$ coal and $50 \mathrm{~g}$ inorganic cultures. Then add different exogenous substances to simulate the influence of different conditions on gas generation. The 1st group is to simulate gas generation of coals utilizing their own nutrients and analyze gas production potential by indigenous bacteria without the addition of exogenous substances; The 2nd to 4th groups are to analyze the production enhancement potential with the addition of exogenous bacteria; The 5th to 7th groups are to analyze the production enhancement potential with the addition of different nutrients; The 8th group is used as the control group. All the samples have been handled under static dark condition at $15^{\circ} \mathrm{C}$ and $35^{\circ} \mathrm{C}$, the whole process has been completed in anaerobic sterile operation box, and gas production tests have been carried out every once in a while and improvements on frequencies have been made.

\begin{tabular}{|c|c|c|c|}
\hline No. & Additive & Experiment Condition & Experiment Objective \\
\hline 1 & $10 \mathrm{~g}$ coal $+50 \mathrm{~g}$ inorganic medium & - & $\begin{array}{l}\text { gas production potential analysis by } \\
\text { indigenous bacterial }\end{array}$ \\
\hline 2 & $10 \mathrm{~g}$ coal $+50 \mathrm{~g}$ inorganic medium & $\begin{array}{c}\text { degrading enrichment by } 10 \mathrm{ml} \text { Anaerobic } \\
\text { hydrocarbon }\end{array}$ & $\begin{array}{l}\text { Gas generation potential analysis } \\
\text { by coals under lab conditions }\end{array}$ \\
\hline 5 & $10 \mathrm{~g}$ coal $+50 \mathrm{~g}$ inorganic medium & $\mathrm{H} 260 \mathrm{ml}$ & Gas generation notential analysis \\
\hline 6 & $10 \mathrm{~g}$ coal $+50 \mathrm{~g}$ inorganic medium & $\mathrm{NaAc}(0.5 \mathrm{M}) 1 \mathrm{ml}$ & with the addition of nutrients \\
\hline 7 & $10 \mathrm{~g}$ coal $+50 \mathrm{~g}$ inorganic medium & $\mathrm{CH}_{3} \mathrm{OH}(0.5 \mathrm{M}) 1 \mathrm{ml}$ & \\
\hline 8 & $10 \mathrm{~g}$ coal $+50 \mathrm{~g}$ inorganic medium & Sterilizing coal samples & Control Group \\
\hline
\end{tabular}

\section{Potential Analysis of Enhancing CBM Production by Microbes}

After 172 days of lab incubation, most of the coal samples have different degrees of gas generation, showing that it is completely possible for coals to produce gas by microbes. Biogas generation is very common under geological conditions. Furthermore, coal samples without gas production could produce gas by adding nutrients or Bacteria, while coal samples with gas production may continue or be restricted to produce gas due to the promotion or destruction of the former gas generating balance with the addition of exogenous substances. 


\subsection{Gas Generation Potential Analysis of Coals Utilizing Indigenous Bacterial}

Without adding any substances, HF, SL and ZC coal samples show good gas production, while in other areas they do not. The reason for this may be associated with the macerals of coal rocks, in which coal samples with higher vitrinite content may produce gas, while coals with higher inertinite content may not produce gas. Methanogens is a kind of anaerobic microbes and may preferentially degrade vitrinite parts of coals. From gas generation experiment(Figure 2), it can be seen that gas generation rate is rapid at the initial period of cultures and then declines after 150 days. Gas generation varies greatly under different temperature gradients and the gas production at $35^{\circ} \mathrm{C}$ is higher than that at $15^{\circ} \mathrm{C}$, indicating that $35^{\circ} \mathrm{C}$ is more suitable for coals to produce gas by microbes, with $0.49 \mathrm{mmol}$ of total gas production, about $0.78 \mathrm{~m}^{3} / \mathrm{t}$.
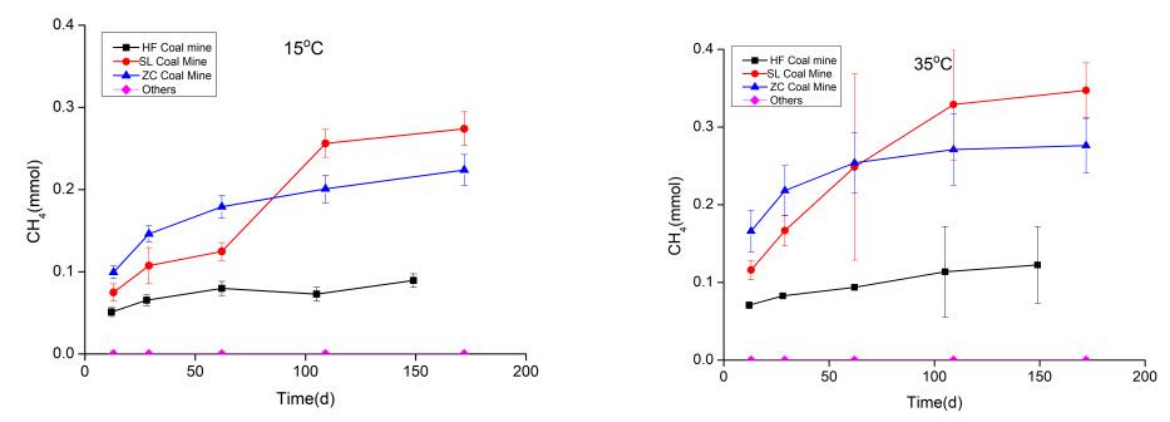

Fig 2 Gas production trends of Inorganic salt enrichment cultures under different temperatures

(the temperatures of $\mathrm{A}$ and Bare $15^{\circ} \mathrm{C}$ and $35^{\circ} \mathrm{C}$, )

\subsection{Production Enhancement Potential Analysis by Adding Bacteria}

Comparison of gas generation has been made between coal sample groups with and without addition of exogenous methanogens, and CK group (coal samples without addition, only including methanogens and inorganic salt). Among them, most bacteria clones of the inoculation(AHB) belong to five groups: uncultured WWE1 (4.8-36.7\%), Clostridiales (8.9-22.8\%), Spirochaetales (7.2-10.1\%), Thermotogaceae (4.8-6.3\%) and Proteobacteria (5.1-6.3\%). Archaea includes acetic acid nutritional methanogenic archaea(Methanosaeta), uncultured Methanomicrobia groups and hydrogen nutritional Methanomicrobiaceae, with hydrogen and acetic acid nutritional methanogenesis archaea coexisting. It could be seen from the gas production curve(Figure 4) that gas production shows an increasing trend after adding exogenous methanogens, indicating that the addition of exogenous bacteria has promoted gas production. 


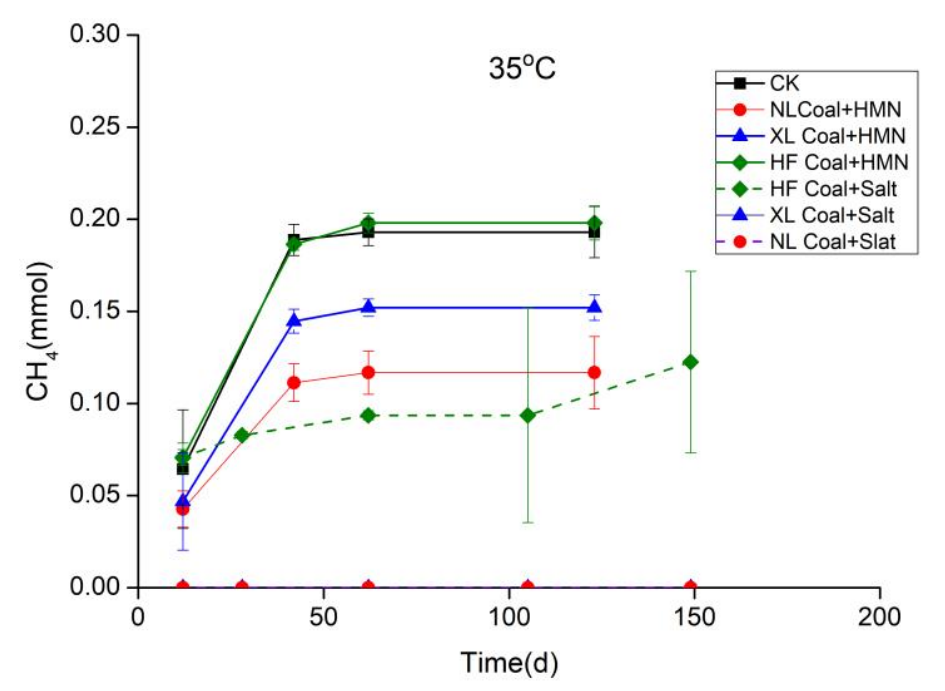

Fig 3 Gas production curve of adding exogenous bacteria

\subsection{Production Enhancement Potential with the Addition of Exogenous Nutrients}

By four control experiments: one without carbon source, the other three with hydrogenation nutrients, NaAc and methanol respectively, coal samples have been cultivated for 135 days under laboratory conditions(Figure 5). It could be seen from the gas production curve that the gas production was $0.1 \mathrm{mmol}$ without adding carbon source, and it has increased when NaAc or hydrogen nutrients are added. Meanwhile, the gas production added with hydrogen nutrients is higher than that by adding NaAc. Moreover, the gas production decreases when adding methanol, indicating an inhibitory effect on gas production. It could be concluded that coal samples may give priority to hydrogen nutrients.

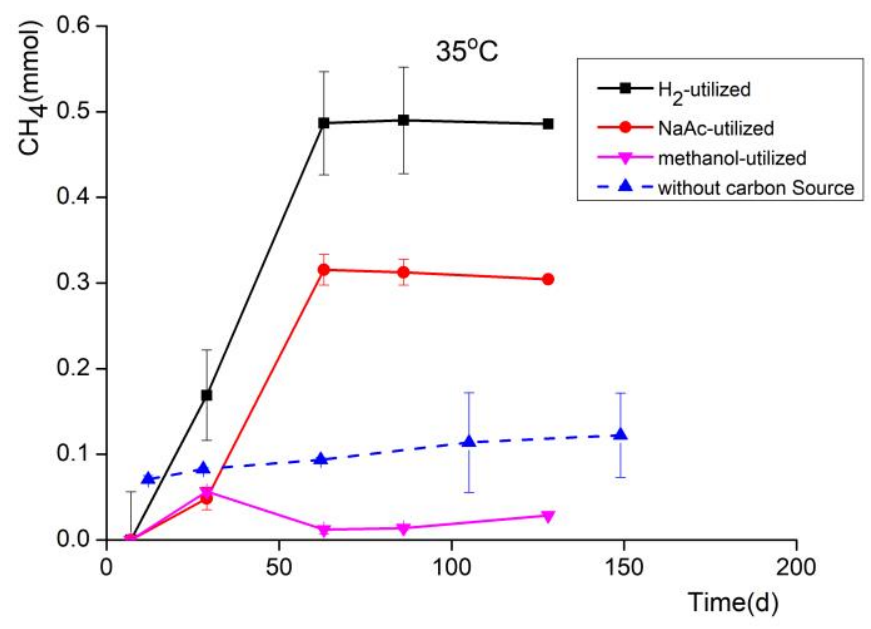

Fig 4 Gas production curve of adding different nutrients

\subsection{Conclusions}


Through biogas simulation experiments, it is found that coals could produce gas by utilizing their own microbes and gas production could be greatly increased by artificial intervention. Gas production by adding exogenous bacterial species is up to $1.68 \mathrm{~m} 3 / \mathrm{t}$, an increase by $115 \%$, while gas production by adding nutrients can reach $1.9 \mathrm{~m} 3 / \mathrm{t}$, an increase by $144 \%$.

Table 6 Gas production of microbes under different conditions

\begin{tabular}{ccccc}
\hline & $\mathrm{Mol} /(\mathrm{mmol})$ & Volume/(ml) & $\begin{array}{c}\text { Equivalent gas } \\
\text { production/ } \\
\left(\mathrm{m}^{3} / \mathrm{t}\right)\end{array}$ & $\begin{array}{c}\text { Increment } \\
\text { Proportion/(\%) }\end{array}$ \\
\hline $\begin{array}{c}\text { Indigenous } \\
\text { microbes } \\
\text { Adding }\end{array}$ & 0.35 & 7.84 & 0.78 & - \\
$\begin{array}{c}\text { Exogenous } \\
\text { Bacterial } \\
\text { Adding }\end{array}$ & 0.75 & 16.8 & 1.68 & 115 \\
nutrients & 0.85 & 19.04 & 1.9 & 144 \\
\hline
\end{tabular}

\section{Biogas Simulation Experiment Prospect}

Coal resources are abundant in China, but as gas content is low in some coal field, it does not deserve CBM commercial development (Qin,2005,2006;Tao,2005;). Research on biogas production shows a clear mechanism of methane generation, and coal seam conditions can be improved by artificial means(Huang ZX,2017; Iverach CP;2017). For example, gas production could be improved by injecting microbes into coals in the areas that lack microbes(Gallagher LK,2013;). Meanwhile, in some areas with biological bacteria, gas production can be promoted by adding nutrients (kotarba,2004;Guo HG,2015) . The simulation experiment, that methanogens can utilize coals to produce biological methane, theoretically justifies the effectiveness of the technology(Green MS,2008). Moreover, as coal seams are shallow with well developed pores, it is technically feasible to inject nutrients and bacteria to enhance CBM production. Currently, a large mount of biogas has been found in $\mathrm{CBM}$ areas in China. Therefore, we can firstly select areas with good geological conditions for biogas development, including areas with active groundwater recharge, large coal reservoir thickness, high permeability and good cap rock, then simulate gas production by laboratory experiment and inject different kinds of nutrients or microbes to accelerate coals or to activate endogenous bacteria to produce gas in order to enhance CBM production. But converting coal beds into methane by improving coalbed environment is still in the phase of laboratory simulation, as many problems remain unsolved in field applications. Nevertheless, this technology has a huge potential and is believed to be the next breakthrough for CBM industrialization.

\section{Acknowledgements}

This paper is funded by the National Science and Technology Key Project "Optimization and Evaluation of Blocks for Large-scale Development of Medium- and Low-rank Coalbed Methane 
(CBM)” (Serial No.: 2016ZX05041) and PetroChina Major Science and Technology “Study and Application of Key Technologies for Exploration and Development of Coalbed Methane” (Serial No.: 2017E14).

\section{References}

Ahmed, M., Smith, J.W.,. Biogenic methane generation in the degradation of eastern Australian Permian coals[J]. Organic Geochemistry .2001,32, $809-816$.

Alexei V. Milkov.Worldwide distribution and significance of secondary microbial methane formed during petroleum biodegradation in conventional reservoirs[J]. Organic Geochemistry $42(2011) 184-207$.

Barnhart, E.P., De León, K.B., Ramsay, B.D., Cunningham, A.B., Fields, M.W., 2013. Investigation of coal-associated bacterial and archaeal populations from a diffusive microbial sampler (DMS). Int. J. Coal Geol. $115,64-70$.

Barnhart, E.P., Weeks, E.P., Jones, E.J.P., Ritter, D.J., McIntosh, J.C., Clark, A.C., Ruppert, L.F., Cunningham, A.B., Vinson, D.S., Orem, W., Fields, M.W., 2016. Hydrogeochemistry and coal-associated bacterial populations from a methanogenic coal bed. Int. J. Coal Geol. 162, $14-26$.

Bi ZT, Zhang J, Park S, et al. A formation water-based nutrient recipe for potentially increasing methane release from coal in situ[J]. Fuel, 2017, 209: 498-508

ChengL, RuiJ, LiQ, ZhangH, LuY. Enrichment and dynamics of novel syntrophs in a methanogenic hexadecane-degrading culture from a Chinese oil field[J].FEMS Microbiology Ecology,2013,83(3):757-766.

Colosimo F, Thomas R, Lloyd JR, Taylor KG, Boothman C, Smith AD, et al. Biogenic methane in shale gas and coal bed methane: A review of current knowledge and gaps[J]. International Journal of Coal Geology, 2016, 165: $106-120$.

Davis KJ, Lu SP, Barnhart EP, et al. Type and amount of organic amendments affect enhanced biogenic methane production from coal and microbial community structure[J]. Fuel, 2018, 211: 600-608.

Dariusz Strapoc .Biogeochemistry of Microbial Coal-Bed Methane[J], Annu. Rev. Earth Planet. Sci. 2011,39:617 $-656$.

Guo H G, Yu Z S, Zhang H X. Phylogenetic diversity of microbial communities associated with coalbed methane gas from Eastern Ordos Basin, China[J]. International Journal of Coal Geology, 2015, 150-151: 120-126. Green MS, Flanegan KC, Gilcrease PC. Characterization of a methanogenic consortium enriched from a coalbed methane well in the Powder River Basin, U.S.A.[J]. International Journal of Coal Geology, 2008, 76(1/2): 34-45 
Gallagher LK, Glossner AW, Landkamer LL, et al. The effect of coal oxidation on methane production and microbial community structure in Powder River Basin coal[J]. International Journal of Coal Geology, 2013, 115: $71-78$

Haider R, Ghauri M A, Rahim M U. On comparison between fungal and bacterial pretreatment of coal for enhanced biogenic methane generation[J]. Geomicrobiology Journal, 2018, 35(5): 432-437.

Haider R, Ghauri MA, SanFilipo JR, Jones EJ, Orem WH, Tatu CA, Akhtar K, Akhtar N. 2013. Fungal degradation of coal as a pretreatment for methane production. Fuel. 104:717 - 25 .

Haider, R., Ghauri, M.A., Jones, E.J., Sanfilipo, J.R., 2014. Methane generation potential of Thar lignite samples. Fuel Process. Technol. 126, $309-314$.

Huang ZX, Sednek C, Urynowicz MA, et al. Low carbon renewable natural gas production from coalbeds and implications for carbon capture and storage[J]. Nature Communications, 2017, 8(1): 568

Iverach CP, Beckmann S, Cendón DI, et al. Biogeochemical constraints on the origin of methane in an al luvial aquifer: evidence for the upward migration of methane from underlying coal measures[J]. Biogeo sciences, 2017, 14: 215-228

Jones EJP, Voytek MA, Warwick PD, Corum MD \& Cohn A. Bioassay for estimating the biogenic methane-generating potential of coal samples[J]. International Journal of Coal Geology, 2008, 76(1): 138-150.

Jones, E.J.P., Voytek, M.A., Corum, M.D., Orem, W.H . Stimulation of methane generation from nonproductive coal by addition of nutrients or a microbial consortium[J]. Appl. Environ, Microbiol,2010, 76, 7013 - 7022.

Kirk MF, Wilson BH, Marquart KA, et al. Solute concentrations influence microbial methanogenesis in coal-bearing strata of the Cherokee Basin, USA[J]. Frontiers in Microbiology, 2015, 6: 1287

KOTARBA M J, LEWAN M D. Characterizing thermogenic coalbed gas from Polish coals of different ranks by hydrous py-rolysis [J]. Organic Geochemistry,2004,35,615 - 646.

Li Mingzhai, Zhang Hongnian, Liu hua, et al. The Progress Of Biogas Simulation Experiment[J]. Journal of Oil And Gas Geology, 1996,(02) .42-51.

M,Martini A, Petsch S. Biodegradation of secondary organic matter associated with coalbed methane in the Power River and San Juan Basin, USA [J]. Int J Coal Geol, 2008, 76: 86-91.

Park SY, Liang Y. Biogenic methane production from coal: A review on recent research and development on microbially enhanced coalbed methane (MECBM)[J]. Fuel, 2016, 166: 258-267.

Priyadarshani, I., Rath, B., 2012. Commercial and industrial applications of micro algae -a review. J. Algal Biomass Util. 3, 89 - 100. 
Qin Yong. Research Progress And Analysis of CBM Formation and Reservoir Property Abroad[J]. Geological Front, 2005, (03) : 289-298.

Qin Yong. Situation and Challenges Faced by Chinese CBM Industrialization( I ) -The Current Development Stage[J]. Journal of Natural Gas Industry, 2006, 26 (1) : 4-7.

Rathi R, Priya A, Vohra M, et al. Development of a microbial process for methane generation from bituminous coal at thermophilic conditions[J]. International Journal of Coal Geology, 2015, 147-148: 25-34

Robbins SJ, Evans PN, Esterle JS, et al. The effect of coal rank on biogenic methane potential and microbial composition[J]. International Journal of Coal Geology, 2016, 154-155: 205-212

Raudsepp MJ, Gagen EJ, Golding SD, et al. The effect of bituminous coal on methanogenic mixed cultures and pure cultures of Methanococcus and Methanosarcina[J]. Fuel, 2017, 205: 60-70

SCOTT A R. Improving coal gas recovery with microbially enhanced coalbed methane [C]//MASTALERZ M, GOLDING S D (Eds) Coalbed Methane: Scientific, Environmental and Economic Evaluation. Kluwer, Dordrecht, 1999: 89-110.

Scott AC, Glasspool IJ. 2007. Observations and experiments on the origin and formation of inertinite group macerals. Int. J. Coal Geol. 70:53 - 66

Stopes M. 1935. On the petrology of banded bituminous coals. Fuel 14:4 - 13.

Strapoc D, Mastalerz M, Dawson K, Macalady J, Callaghan AV, Wawrik B, Turich C, Ashby M. 2011. Biogeochemistry of microbial coal-bed methane. Ann Rev Earth Planet Sci. 39:617 - 56.

Tao mingxin . Current Situation and Development Trend of CBM Geochemical Research[J]. Progress In Natural Science, 2005 (15), 648-652.

Taylor GH, Teichmuller M, Davis A, Diessel CFK, Littke R, Robert R. 1998. Organic Petrology. Berlin/Stuttgart: Gebr ${ }^{*}$ uder Borntraeger. 704 pp.

Wawrik B, Mendivelso M, Parisi VA, et al. Field and laboratory studies on the bioconversion of coal to methane in the San Juan Basin[J]. FEMS Microbiology Ecology, 2012, 81(1): 26-42

Wang BY, Tai C, Wu L, et al. Methane production from lignite through the combined effects of exogenous aerobic and anaerobic microflora[J]. International Journal of Coal Geology, 2017, 173: 84-93

Wang Aikuan, Qin Yong. Research Status and Progress of Biogenic Coalbed Methane Experiment[J]. Journal of Coal Geology and Exploration, 2010, 42 (5) : 23-27.

Wang Aikuan. Gas Generation Characteristics and Mechanism of Indigenous Bacteria in Lignite[D]. China Mining University, 2010. 12 to 24 
Walter B. Ayers Jr. Coalbed gas systems, resources, and production and a review of contrasting cases from the San Juan and Powder River basins.AAPG Bulletin, v. $\quad$ 86, no. 11 (November 2002), pp. 1853 - 1890

WiddelF, BoetiusA, RabusR. Anaerobic biodegradation of hydrocarbons including methane[J]. The Prokaryotes: Ecophysiology and Biochemistry, 2006(2):1028-1049.

Wei M, Yu ZS, Jiang Z, et al. Microbial diversity and biogenic methane potential of a thermogenic-gas coal mine[J]. International Journal of Coal Geology, 2014, 134-135: 96-107.

Yang XQ, Chen YM, Wu RW, et al. Potential of biogenic methane for pilot-scale fermentation ex situ with lump anthracite and the changes of methanogenic consortia[J]. Journal of Industrial Microbiology \& Biotechnology, 2018, 45(4): 229-237

ZEHNDER A J B. Biology of anaerobic microorganisms [M]. New York: John Wiley and Sons, 1988: 2-5.

ZHANG Daoyong, ZHU Jie, ZHAO Xianliang, et al. Dynamic assessment of coalbed methane resources and availability in China [J]. Journal of China Coal Society, 2018, 43( 6) : 1598-1604.

Zhang J, Liang YN, Pandey R, et al. Characterizing microbial communities dedicated for conversion of coal to methane in situ and ex situ[J]. International Journal of Coal Geology, 2015, 146: 145-154.

Zhang J, Liang YN. Evaluating approaches for sustaining methane production from coal through biogasification[J]. Fuel, 2017, 202: 233-240. 